\title{
TOKSISITAS MERKURI TERHADAP KESEHATAN IKAN
}

\author{
Intan Nazarah ${ }^{1}$, Muhammad Radhi ${ }^{1}$ \\ ${ }^{1}$ Mahasiswa Program Studi Akuakultur. Fakultas Pertanian, Universitas Almuslim, Jalan Almuslim, Matang \\ Geulumpang Dua, Peusangan, Kabupaten Bireuen, Aceh 24261 \\ Email:nazarahintan@gmail.com
}

\begin{abstract}
ABSTRAK
Uji toksikan bertujuan untuk membantu menentukan tingkat toksikan dari suatu zat atau polutan. merkuri memiliki potensi sebagai bahan pencemar yang memiliki dampak terhadap organisme yang tinggal di dalam perairan. organisme yang berpotensi terpapar adalah ikan yang terpapar merkuri dan berdampak terhadap kerusakan organ. pada insang yaitu aktivitas enzim yang ada pada insang terganggu dan oragan insang menjadi rusak, efek negatif pada hati adalah dengan turunnya aktivitas enzim yang akan menghambat proses metabolisme pada hati yang berdampak terhadap turunnya bobot hsi (bobot hati) dan juga terjadi peningkatan cairan empedu, selain itu efek negatif yang terdapat pada ginjal yaitu terjadinya perubahan organ - organ ginjal pada setiap konsentrasi yang berbeda. dan efek negatif pada lambung yaitu menurunnya kinerja enzim yang berdampak pada penurunan nafsu makan ikan.
\end{abstract}

Kata Kunci: Toksisitas, Merkuri, Organ-organ ikan.

\section{PENDAHULUAN}

Toksisitas adalah tingkat merusaknya suatu zat jika terkena terhadap organisme. Meningkat nya kadar zat-zat pencemar yang berbahaya dapat menimbulkan toksik atau racun sehingga mengganggu proses kehidupan dan setelah mencapai kadar tertentu dapat mematikan hewan peliharaan (Zulfahmi et al., 2017); (Zulfahmi et al., 2018); (Akmal et al., 2018d); (Muliari et al., 2019a); (Muliari et al., 2019b). Ikan salah satu organisme sangat rentan terhadap toksikan logam jika terusmenerus terpapar di media hidupnya dan dapat zat toksikan tersebut dapat masuk melalui insang dan pakan yang terkontaminasi. Faktor lingkungan seperti toksik perairan dari dan kelainan genetik dapat mempengaruhi keabnormalan tulang rangka ikan (Zulfahmi et al., 2018); (Akmal et al., 2018a); (Akmal et al., 2018b); (Akmal et al., 2018c); (Akmal et al., 2018c); (Zulfahmi et al., 2019). Efek dari bahan pencemar ini, dapat mengakibatkan kerusakan organ-organ tubuh ikan. Merkuri ( $\mathrm{Hg})$ merupakan salah satu logam berat yang sangat banyak ditemukan dalam perairan dan sedimen (Ullrich et a,l. 2001). Meskipun terjadi secara alami, aktivitas manusia telah memobilisasi meningkatnya jumblah merkuri dan menjadi sumber masalah kesehatan bagi masyarakat (Clarkson, 2006). Logam berat ini sangat signifikan dalam hal daya racunnya. Selain itu, merkuri tidak dapat terurai oleh bakteri sehingga tetap berada dalam perairan dan sedimen secara permanen (Clark, 2001).

Merkuri $(\mathrm{Hg})$ merupakan salah satu logam berat yang sangat berbahaya walaupun dalam kadar yang sedikit (Kehrig et al,. 2002). Menurut Palar (2004) merkuri yang masuk kedalam perairan secara alami tidak memberikan efek - efek dikarenakan alam dapat mentolerir. Merkuri menjadi bahan pencemar sejak manusia mengenal industri. Merkuri sangat berdampat terhadap mortalitas ikan menurut Zulfahmi (2017) semakin tinggi konsentasi merkuri yang terkena pada media uji maka mortalitas ikan semakin meningkat. dalam uji toksisitas akut kematian ikan secara cepat terjadi karena rusaknya organ - organ ikan. Menurut Ay et al,. (1999) insang sangat berpeluang terkonstaminasi toksikan karna insang bersentuhan langsung dengan media air. (Roberts 1978).

Insang merupakan organ yang berfungsi dalam mengatur pertukaran ion, pertukaran gas, menjaga keseimbangan $\mathrm{pH}$ dan ekskresi nitrogen (Mathan et al,. 2010); (Akmal et al., 2018);. Menurut Loomis (1979) selain insang, hati merupakan juga organ yang banyak berhubungan dengan senyawa kimia sehingga mudah terkena efek toksikan di karenakan diantara berbagai zat yang masuk bersama darah, kemungkinan besar ada zat yang dapat menyebabkan kerusakan organ hati. Menurut Zulfahmi (2017) hati merupakan organ utama untuk melakukan biotransformasi berbagai macam bahan kimiawi. Menurut Tresnati (2013) toksikan logam berat dapat mengakibatkan kerusakan jaringan terutama pada organ hati dan ginjal. Ginjal berfungsi untuk menyaring dan membuang zat yang sudah tidak diperlukan oleh tubuh, termasuk bahan racun seperti logam berat. Hal tersebut yang menyebabkan ginjal sering mengalami kerusakan oleh daya toksik logam (Palar 1994). Merkuri bisa menyebabkan berbagai kerusakan pada organ ikan. Salah satunya pada organ pencernaan ikan (Darmono, 2001). Lambung merupakan salah satu bagian dari organ pencernaan pada ikan. Di dalam lambung terjadi proses pencernaan secara mekanik dan kimiawi (Fujaya,2004). 


\section{PEMBAHASAN}

\section{Kerusakan pada insang}

Kematian ikan secara cepat dalam uji toksisitas akut terjadi karena rusaknya organ pernafasan ikan . Insang sangat berpeluang terkena toksikan dikarenakan insang terkena langsung dengan media air (Roberts 1978). Dan jaringan insang yang tersusun atas jaringan epitel tipis, dan secara langsung berhubungan dengan zat toksik yang ada di lingkungan, menyebabkan insang mengalami kerusakan (Roberts 1978). Pemaparan merkuri menyebabkan gangguan kinerja insang yang ditandai dengan cepatnya pergerakan operkulum sesaat setelah pemaparan merkuri (Zulfahmi et al,. 2017) Menurut (Purnomo dan Muchyiddin 2007) hal ini dikarenakan insang sangat sensitif terhadap pengaruh toksikan logam berat merkuri dan juga pada kondisi terkena logam berat aktivitas enzim yang ada pada insang juga terganggu. Kerusakan insang dapat terjadi akibat pengikatan merkuri oleh lendir melewati lamella dan pada kadar yang lebih besar mampu menghambat proses pertukaran gas-gas dan ion pada lamella sehingga sistem respirasi ikan terhambat dan dapat menimbulkan kematian. Secara histopatologi, kerusakan jaringan insang akibat paparan merkuri meliputi hipertropi, hyperplasia, vakuolalisasi, ketidaklurusan pada lamella sekunder (curling of secondary lamella), berhimpitnya lamella sekunder (Proliferasi), dan kematian Sel (Muliari et al., 2019a).

\section{Kerusakan pada hati}

Pemaparan merkuri dapat mengakibatkan terganggunya kondisi hati ikan. Hati merupakan organ utama yang berfungsi dalam biotransformasi berbagai macam bahan kimiawi (Muliari et al., 2019a). Organ hati sangat peka terhadap paparan dari semua toksikan logam berat yang berada di lingkungan perairan (Zulfahmi et al, 2017). Palar (2004) menjelaskan bahwa paparan merkuri dapat mengganggu kerja enzim-enzim yang berada di dalam hati. Meningkatnya akumulasi merkuri di dalam hati menyebabkan penurunan kinerja enzim yang ada di hati (Henczová et al,. 2008). Gangguan pada hati dapat menganggu proses vitalogenesis yang berakibat negatif terhadap perkembangan gonad ikan (Zulfahmi et al., 2017). Turunnya kinerja enzim yang berada di dalam hati akan berpotensi terganggunya proses metabolisme di dalam hati, yang akan mengakibatkan turunnya bobot hati (HSI). Turunnya bobot hati tersebut disebabkan oleh vakuolalisasi sitoplasma diikuti dengan mengecilnya inti sel yang berdampat terhadap turunnya nilai HSI (Lam et al,. 2006). Perubahan nilai HSI ini memperlihatkan bahwa ukuran dan bobot sel hati menjadi berkurang akibat adanya pemaparan dari toksikan logam merkuri
(Figueiredo-Fernandes et al,. 2006). Merkuri di dalam hati terbagi menjadi dua bagian, bagian pertama terakumulasi dalam hati dan yang lainnya akan masuk ke empedu (Palar 2004). Cairan empedu merupakan hasil pembuangan dari hati yang memiliki berfungsi untuk menghancurkan lemak sehingga lemak menjadi mudah dicerna dan di serap oleh usus, selain itu juga cairan empedu juga berfungsi sebagai media untuk ekskresi. Dampak merkuri terhadap cairan empedu yaitu dengan meningkatnya akumulasi merkuri pada ikan maka akan menyebabkan tingginya volume cairan empedu pada tubuh ikan (Zulfahmi et al, 2017); (Muliari et al., 2019a). Paparan merkuri juga memyerang organ ikan lainnya yaitu ginjal dan organ pencernaan (lambung).

\section{Kerusakan ginjal.}

Menurut Tresnati (2013) terjadi perubahan pada organ - organ ginjal ikan Pari kembang (Dasyatis kuhlii) karena adannya paparan logam berat merkuri $(\mathrm{Hg})$ dengan konsentrasi yang berbeda. Pada konsentrasi rendah $(0,025)$ kerusakan yang terjdi Hyaline droplet. Hyaline droplet merupakan salah satu perubahan pada organ ginjal yang berakibat pada penurunan fungsi ginjal, berupa penumpukan massa sitoplasma yang tampak menonjol. Menurut Takashima dan Hibiya (1995) kondisi ini ditandai dengan bentuk glomerulus dan renal tubule nampak tidak jelas dan memproduksi granula secara berlebih. Hyaline droplet adalah gejala kerusakan ginjal yang ditemukan pada tingkat pencemaran yang rendah. Ini berupa tumor pada ginjal ikan atau organisme dalam perairan. Pada pemaparan merkuri dengan konsentrasi lebih tinggi $(0,1)$ ditemukan hypertrophy, atrophy dan hyperplasia. hypertrophy merupakan membesarnya jaringan akibat membesarnya sel-sel dalam jaringan renal tubuluse ( Tresnati, 2013). Menurut Takashima dan Hibiya (1995) mengemukakan bahwa atrophy merupakan kerusakan sel yang disebabkan oleh terhambatnya pertumbuhan sel di bawah normal sehingga terbentuk suatu ruangan atau rongga dalam jaringan. Dan atrophy ini di tandai dengan menyusutnya ukuran dari renal tubuluse dan glomerulus. Hyperplasia terjadi pada glomerulus yang di tandai dengan bertambahnya sel - sel di dalam jaringan terlihat semakin meningkat volume dari ukuran normal. Dan pada tingkat kosentrasi yang paling tinggi tinggi $(0,2)$ Ditemukan kematian jaringan (necrosis). Takashima dan Hibiya (1995) mengemukakan bahwa necrosis adalah kerusakan jaringan karena matinya sel dan tidak dapat berfungsi lagi dalam mengambil nutrisi dikarenakan sel - selnya sudah rusak hal ini ditandai dengan ditandai dengan menghitamnya jaringan pada preparat histologi.

\section{Kerusakan organ pencernaan (lambung)}

Menurut Ezraneti (2005) lambung ikan yang 
terkena merkuri mengalami kerusakan hal ini terlihat dari hasil pengukuran yang menunjukan bahwa lapisan otot dan laposan vili mengalami pembengkakan. Hal ini di sebabkan karena ikan meminum air yang mengandung merkuri dengan konsentrasi yang cukup tinggi dan melebihi toleransi tubuh ikan. Merkuri yang ada dalam periairan juga berdampak pada kinerja enzim di karenakan enzim yang ada dalam lambung berikatan dengan merkuri yang ada dalam air. Sel mukosa yang ada di seluruh permukaan lambung akan mensekresi lendir yang berlebih dan akan menutupi seluruh permukaan lambung. Kondisi seperti ini berlangsung lama sehingga pada beberapa bagian permukaan lambung terdapat kerusakan pada lapisan epitelnya bahkan ada yang sampai lepas. Hal ini menyebabkan ikan kehilangan nafsu makan karena proses pencernaannya terganggu dan pada akhirnya proses metabolisme juga terganggu (Suleha, 2005).

\section{KESIMPULAN}

Toksisitas adalah tingkat merusaknya suatu zat jika dipaparkan terhadap organisme. Efek negatif dari merkuri berpotensi merusak organ - organ ikan seperti insang, hati, ginjal, dan organ pencernaan (lambung). Pada insang yaitu menyebabkan aktivitas enzim yang ada pada insang terganggu dan organ insang menjadi rusak dikarenakan insang sangat sensitif terhadap toksikan logam berat, efek negatif pada hati adalah dengan turunnya aktivitas enzim yang akan menghambat proses metabolisme pada hati yang berdampak terhadap turunnya bobot HSI (bobot hati) dan terjadi peningkatan cairan empedu hal ini dikarenakan meningkatnya akumulasi merkuri dalam hati ikan dan merkuri terekskresi dalam hati, selain itu efek negatif yang terdapat pada ginjal yaitu pada kosentrasi merkuri yang sangat tinggi merkuri dapat menyebabkan necrosis atau kerusakan sel karena rusaknya ezim yang ada dalam proses metabolisme dalam hati. Dan efek negatif pada lambung yaitu dengan meningkatnya merkuri dalam lambung maka menurunnya kinerja enzim yang berdampak pada penurunan nafsu makan ikan.

\section{DAFTAR PUSTAKA}

Akmal, Y., Saifuddin, F., \& Zulfahmi, I. (2018). Anatomi Skeleton Ikan Keureling. In Prosiding Seminar Nasional (Vol. 1, No. 1).

Akmal, Y., \& Rahardjo, M. F. (2018). Morphology of appendicular skeleton of the Thai mahseer's Tor tambroides (Bleeker, 1854). Jurnal Iktiologi Indonesia, 18(3),261-274. https://doi.org/10.32491/jii.v18i3.443

Akmal, Y., Zulfahmi, I., \& Saifuddin, F. (2018). Karak-teristik morfometrik dan skeleton ikan keureling (Tor tambroides Bleeker 1854). Jurnal Ilmiah Samudra Akuatika, 2(1), 35-44.

Akmal, Y., Zulfahmi, I., Juanda, R., Karja, N. W. K.,
\& Nisa, C. (2018, December). Histopathological changes in gill of Nile tilapia (Oreochromis niloticus) after palm oil mill effluent exposure. In IOP Conference Series: Earth and Environmental Science (Vol. 216, No. 1, p. 012003). IOP Publishing.

Akmal, Y., Saifuddin, F., \& Zulfahmi, I. (2019). Karakteristik Morfometrik Dan Studi Osteologi Ikan Keureling. Prosiding Biotik, 5(1).

Ay,Ö,. Kalay, M,. Tamer, L,. Canli, M. (1999). Copper and lead accumulation in tissues of a freshwater fish Tilapia zillii and its effects on the branchial $\mathrm{Na}+/ \mathrm{K}+-\mathrm{ATPase}$ activity. Bulletin Environmental Contamination and Toxicology, 62(2):160-168.

Clark, R. (2001). Marine pollution. Oxford University Press. New York. 231 p.

Clarkson, TW,. Magos, L.(2006). The toxicology of mercury and its chemical compounds. Critical Reviews in Toxicology, 36(8):609-662.

Darmono. (2001). Lingkungan Hidup dan Pencemaran. Universitas Indonesia (UI-Press). Jakarta.

Ezraneti, R. (2005). Histoligi lambung benih ikan kakap putih (Lates calcarifer bloch) yang terpapar merkuri nitrat $[\mathrm{Hg}$ (NO3)2] dengan konsentrasi berbeda Acta Aquatica, 2 (1): 6669.

Figueiredo-Fernandes, A, A,. Ferrera-Cardoso, JV, Garcia-Santos, S,. Monteiro, SM,. Carrola, J, Matos, Fontainhas-Fernandes. (2006). Histopathological changes in liver and gill epithelium of Nile tilapia, (Oreochromis niloticus), exposed to waterborne copper. Pesquisa Veterinária Brasileira, 27(3) :103-109

Fujaya, Y,. (2004). Fisiologi Ikan (Dasar Pengembangan Teknik Perikanan). Rineka Cipta. Jakarta. 179 Halaman Comparative Biochemistry and Physiology, (148) :53-60.

Henczová, M,. Deér, AK,. Filla, A, Komlósi, V,. Mink, J,. (2008). Effects of $\mathrm{Cu} 2+$ and $\mathrm{Pb} 2+$ on different fish species: Liver cytochrome P450dependent monooxygenase activities and FTIR spectra. Comparative Biochemistry and Physiology, (148): 53-60.

Kehrig, HA,. Costa, M,. Moreira, I, Malm, O, (2002). Total and methyl mercury in a Brazilian estuary, Rio de Janeiro. Marine Pollution Bulletin, 44 (10): 1018-1023.

Lam, SH,. Winata, CL,. Tong, Y,. Korzh, S,. Lim, WS,. Korzh, V. (2006). Transcriptome kinetics of arsenic-induced adaptive response in zebrafish liver. Physiological Genomics, 27 (3): 351-61.

Loomis, TA. (1978). Toksikologi Dasar. Penerjemah Donatus. Semarang: IKIP.

Mathan, R,. Kurunthachalam, SK,. Priya, M,. (2010). Alterations in plasma electrolyte levels of a freshwater fish (Cyprinus carpio) exposed to acidic $\mathrm{pH}$. Toxicological Environmental and 
Chemistry, 92 (1): 149-157.

Muliari, M., Zulfahmi, I., \& Akmal, Y. (2019a). Ekotoksikologi Akuatik. Bogor: IPB Press.

Muliari, M., Zulfahmi, I., Akmal, Y., Karja, N. W. K., Nisa, C., \& Sumon, K. A. (2019b). Effects of palm oil mill effluent on reproductive hormone of female nile tilapia, oreochromis niloticus (linnaeus 1758). Adv. Anim. Vet. Sci, 7(11), 1035-1041.

Palar, H,. (1994). Pencemaran dan Toksikologi Logam Berat. PT Rineka Cipta. Jakarta.

Palar, H,. (2004). Pencemaran dan toksikologi logam berat. Penerbit Rineka Cipta. Jakarta. $152 \mathrm{hlm}$.

Purnomo, T,. Muchyiddin. (2007). Analisis kandungan timbal $(\mathrm{Pb})$ pada ikan bandeng (Chanos chanos Forsk.) di Tambak Kecamatan Gresik. Neptunus, 14(1):68-77.

Roberts, R, J. (1978). Fish pathology. Bailliere Tindal. London. $571 \mathrm{p}$.

Saleha, (2005). Toksisitas Mercury Nitrat $\mathrm{Hg}(\mathrm{NO} 3) 2$ Terhadap Benih Ikan Kakap Putih (L. calcarifer, Bloch). Skripsi. Fakultas Perikanan dan Ilmu Kelautan. Universitas Riau. Pekanbaru. $57 \mathrm{Hal}$.

Takashima, F, and T. Hibiya, (1995). An Atlas of Fish Histology. 2nd Edition Kondansha Ltd. Jepang. $195 \mathrm{p}$.

Tresnati, J. (2013). Perubahan Jaringan Ginjal Ikan Pari Kembang (Dasyatis kuhlil) Akhibat Paparan Logam Merkuri (Hg). Jurnal Akuatika, 2013.

Ullrich, SM, Tanton TW, Abdrashitova, S,A. (2001). Mercury in the aquatic environment: a review of factors affecting methylation. Critical Reviews in Environment Science and Technology, 31(3):241-93

Zulfahmi, I,. Ridwan, Affandi, and Djamar TF Luman Batu, (2017a) "Kondisi biometrik ikan nila, (Oreocromis niloticus Linnaeus 1758) yang terpapar merkuri [Biometric niloticus (Linnaeus 1789) after mercury 14.1:37-48.

Zulfahmi, I., Akmal, Y., \& Batubara, A. S. (2018). The morphology of Thai mahseer's Tor tambroides (Bleeker, 1854) axial skeleton (ossa vertebrae). Jurnal Iktiologi Indonesia. Jurnal Iktiologi Indonesia, 18(2), 139-146. https://doi.org/10.32491/jii.v18i2.329

Zulfahmi, I., Akmal, Y., \& Muliari, M. (2019). Osteologi Ikan Keureling (Tor tambroides). Bogor: IPB Press.

Zulfahmi, I., Muliari, M., \& Akmal, Y. (2017, November). Indeks Hepatosomatik Dan Histopatologi Hati Ikan Nila (Oreochromis Niloticus Linnaeus 1758) Yang Dipapar Limbah Cair Kelapa Sawit. In Prosiding SEMDIUNAYA (Seminar Nasional Multi Disiplin Ilmu UNAYA) (Vol. 1, No. 1, pp. 301-314).

Zulfahmi, I., Muliari, M., Akmal, Y., \& Batubara, A. S. (2018). Reproductive performance and gonad histopathology of female Nile tilapia (Oreochromis niloticus Linnaeus 1758) exposed to palm oil mill effluent. The Egyptian Journal of Aquatic Research, 44(4), 327-332. https://doi.org/10.1016/j.ejar.2018.09.003 